\title{
Minicircle Biopharmaceuticals-An Overview of Purification Strategies
}

\author{
Cláudia P. A. Alves ${ }^{1}$, Duarte Miguel F. Prazeres ${ }^{1,2}$ and Gabriel A. Monteiro ${ }^{1,2 *}$ \\ ${ }^{1}$ iBB- Institute for Bioengineering and Biosciences, Instituto Superior Técnico, Universidade de Lisboa, Lisboa, Portugal, \\ ${ }^{2}$ Department of Bioengineering, Instituto Superior Técnico, Universidade de Lisboa, Lisboa, Portugal
}

OPEN ACCESS

Edited by:

Cristina Chuck-Hernandez, Monterrey Institute of Technology and Higher Education (ITESM), Mexico

Reviewed by: Cristiana Boi, University of Bologna, Italy Nafiseh Sanei-Ataabadi,

Royan Institute, Iran Martin Schleef, PlasmidFactory GmbH \& Co. KG,

Germany

*Correspondence:

Gabriel A. Monteiro

gabmonteiro@tecnico.ulisboa.pt

Specialty section:

This article was submitted to

Separation Processes,

a section of the journal

Frontiers in Chemical Engineering

Received: 30 September 2020

Accepted: 15 December 2020

Published: 13 January 2021

Citation:

Alves CPA, Prazeres DMF and Monteiro GA (2021) Minicircle Biopharmaceuticals-An Overview of

Purification Strategies.

Front. Chem. Eng. 2:612594.

doi: $10.3389 /$ fceng.2020.612594
Minicircles are non-viral delivery vectors with promising features for biopharmaceutical applications. These vectors are plasmid-derived circular DNA molecules that are obtained in vivo in Escherichia coli by the intramolecular recombination of a parental plasmid, which generates a minicircle containing the eukaryotic therapeutic cassette of interest and a miniplasmid containing the prokaryotic backbone. The production process results thus in a complex mixture, which hinders the isolation of minicircle molecules from other DNA molecules. Several strategies have been proposed over the years to meet the challenge of purifying and obtaining high quality minicircles in compliance with the regulatory guidelines for therapeutic use. In minicircle purification, the characteristics of the strain and parental plasmid used have a high impact and strongly affect the purification strategy that can be applied. This review summarizes the different methods developed so far, focusing not only on the purification method itself but also on its dependence on the upstream production strategy used.

Keywords: minicircle DNA, non-viral DNA vector, gene therapy, biopharmaceuticals, purification, chromatography

\section{INTRODUCTION}

Biopharmaceuticals are classically defined as a pharmaceutical drug with active agents of biological origin that are manufactured by biotechnological processes. One of the main advantages of biopharmaceutical products is their higher specificity and activity in comparison to conventional drugs. The modern era of biopharmaceuticals started with the approval of Humulin, a therapeutic recombinant insulin developed by Genentech that was approved by the Food and Drug Administration (FDA) and commercialized by Eli Lilly in 1982 (Walsh, 2003; Rader 2008). Since then, the field has been marked by a continuous increase in the number and types of biopharmaceuticals developed and marketed to treat diseases such as cancer, inflammation-related conditions, hemophilia and diabetes. Biopharmaceuticals encompass a wide range of products such as antibodies (which currently hold the highest number of product approvals), recombinant enzymes, cell-based therapies and nucleic-acid based products, among others. Specifically in the area of nucleic acid based products, several types are reported, namely antisense oligonucleotides, aptamers, modified RNA molecules, small interfering RNAs, gene therapy vectors and DNA or RNA vaccines (Walsh 2018). Broad and comprehensive analysis of the progress and developments on the nucleic acid biopharmaceutical field can be found in recent reviews (e.g., Prazeres and Monteiro 2014; Uludag et al., 2019).

Gene therapy is currently defined as the delivery of vectors carrying extra genetic material into cells, with the aim of treating or curing a disorder by modification of endogenous gene expression (Kay 2011). The area has attracted an ongoing interest by the scientific community, as can be 
inferred by the more than 3,000 clinical trials reported since 1989 (Wiley 2019). ${ }^{1}$ Vectors used in gene therapy can be classified as viral (e.g., adenoviruses, retroviruses, lentiviruses) or non-viral (e.g., plasmid DNA, RNA). To date, viral vectors are still the predominant type reported in clinical trials with adenoviral being the most used (18.5\% of the trials), while naked plasmid DNA (pDNA) accounts for 14.9\% (Wiley 2019). ${ }^{1}$ The main reason for the preference for viral vectors is their high transfection efficiency. However, their immunogenicity and capability to promote gene disruption and reacquire replication competency have raised several safety concerns and highlighted the need to develop safer alternatives. This resulted in the introduction of pDNA as a non-viral vector for delivery of nucleic acids (Prather et al., 2003; Hardee et al., 2017).

The potential of non-viral vectors relies not only on their safer characteristics when compared with their viral counterparts, but also in a non-limited number of administrations and an easier and less costly production allied with longer shelf life (Hardee et al., 2017). However, pDNA vectors have some limitations when compared with viral vectors, namely their lower transfection efficiencies and the transient nature of transgene expression, due to their non-replicative nature in eukaryotic cells. The main inherent characteristics of pDNA vectors that affect their transfection efficiency are (i) vector size (smaller vectors can easily enter the cells and reach the nucleus), (ii) plasmid topology, with the supercoiled isoform being the most therapeutically valuable, and (iii) vector DNA content (Mairhofer and Grabherr 2008; Hardee et al., 2017).

The presence of sequences of bacterial origin such as antibiotic resistance genes and the bacterial replication origin needed for amplification in bacterial hosts in the pDNA vector backbone, is undesirable and decreases their clinical potential. Also, the presence of unmethylated $\mathrm{CpG}$ motifs commonly found in prokaryotic DNA can trigger immune responses. Although this can be valuable for DNA vaccination, these sequences are a disadvantage if the vector is intended to be used for delivery in gene therapy (Mairhofer and Grabherr 2008; Hardee et al., 2017). Altogether, the drawbacks of the typical pDNA vector triggered the development of safer and more efficient non-viral delivery vectors, a topic that has been the focus of several reviews [e.g., (Mairhofer and Grabherr 2008; Schleef et al., 2010; Hardee et al., 2017; Shankar et al., 2017)].

The development of vectors free from antibiotic resistance genes was achieved with the creation of plasmids (i) pORT (a plasmid that contains operator sequences which titrate repressors and confers to plasmid-harboring bacteria survival advantage), (ii) pCOR, and (iii) pFAR. In the last two cases, genome engineered producer strains are needed, as the plasmids harbor sequences complementary to strain mutations that renders cells unable to survive if not harboring the corresponding plasmid. Reports indicate successful results for a DNA vaccine against HIV-1 in pre-clinical and clinical studies (pORT, Mwau et al., 2004) and higher transgene expression than

${ }^{1} \mathrm{http} / /$ www.abedia.com/wiley/ promoted by regular plasmids (pCOR and pFAR) (Mairhofer and Grabherr 2008; Hardee et al., 2017). Knowledge of the negative effects of sequences of prokaryotic origin on the transfection efficiency and transgene expression led to development of further improved vectors. Covalently closed vectors (minicircles, minivectors and Miniknot) and linear covalently closed vectors (MIGDE, MiLV and ministrings) can be mentioned in this category. The application of linear covalently closed vectors in gene therapy and DNA vaccination is hindered by some disadvantages such as an inherent expensive production (MIDGE), possible incorrections in the desired sequence (MiLV) or failure to address one of the specifications for nonviral vectors due to the presence of antibiotic in the final product (ministrings). In the case of circular covalently closed vectors, minivectors have been poorly studied and Miniknot vectors are still only a hypothetical suggestion (Tolmachov 2010), which appears to not have been applied so far. Minicircles, however, have been the subject of several studies, which in general report high transfection efficiencies and prolonged transgene expression (Hardee et al., 2017).

Minicircles are supercoiled non-viral DNA delivery vectors that are obtained from a pDNA molecule (parental plasmid). They contain only the eukaryotic cassette of interest, which includes the therapeutic transgene under the control of an eukaryotic promoter and other regulatory sequences, and a short segment of prokaryotic DNA, which is left over after recombination. Due to the absence of a prokaryotic backbone (e.g., antibiotic resistance marker, replication origin), minicircles are smaller and safer than pDNA as delivery vectors for gene therapy (Mairhofer and Grabherr 2008; Hardee et al., 2017). Although minicircles are inherently transient vectors, the inclusion of scaffold/matrix attachment regions (S/MAR) into the eukaryotic cassette can confer episomal maintenance. While only a few S/MAR sequences have been validated, their use can enable minicircle replication at each eukaryotic cell cycle. This makes it possible to maintain the vector as an episome in daughter cells if a more persistence transgene expression is desired (Hardee et al., 2017). However, the inclusion of these regions can have an negative impact on transfection efficiency, given the large length of S/MAR sequences $(\approx 5 \mathrm{~kb})$. Interesting and detailed reviews on the applications of minicircles can be found elsewhere (e.g., Gaspar et al., 2015; Shankar et al., 2017).

The potential of minicircles as DNA vaccines has been demonstrated, as exemplified by the successful intradermal immunization of mice to elicit antigen-specific $\mathrm{CD}^{+} \mathrm{T}$-cell responses against Listeria monocytogenes (Dietz et al., 2013) and intramuscular injection of mice to trigger an immune response against HIV-1 (Wang et al., 2014). Several gene therapy preclinical studies have also been conducted with minicircles. Examples include the generation of induced pluripotent stem cells (iPSC) (Jia et al., 2010) and the genetic modification of human hematopoietic stem cells (Holstein et al., 2018). The use of minicircles for the generation of CAR T-cells has also been reported recently (Monjezi et al., 2017; Wang et al., 2020).

Although no clinical trial has been reported up to date using minicircle DNA vectors (Wiley 2019), ${ }^{2}$ minicircles are viewed as a 


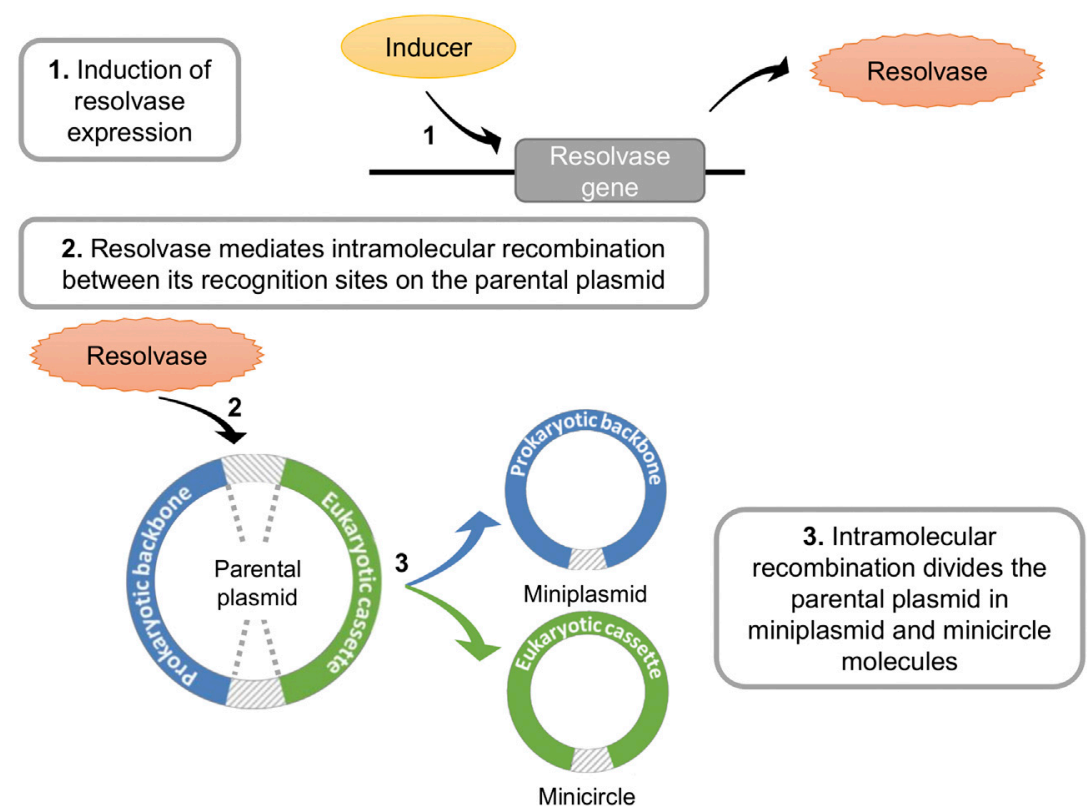

FIGURE 1 | Schematic representation of in vivo parental plasmid intramolecular recombination. Following induction, a resolvase is expressed that mediates intramolecular recombination between recognition sites in a parental plasmid molecule. This results in the formation of a miniplasmid with the prokaryotic backbone and a minicircle with the eukaryotic cassette. Recognition sites for the recombinase are indicated by gray diagonal stripes.

promising biopharmaceutical product for gene therapy and DNA vaccination applications.

Minicircle production is accomplished in vivo in Escherichia coli via induction of intramolecular recombination of a parental plasmid. This process (Figure 1) relies on the expression of a site-specific recombinase that acts upon two recognition sequences. These sites are strategically placed in the backbone of the parental plasmid, flanking the regions dedicated to replication in E. coli (prokaryotic backbone harboring the replication origin and antibiotic resistance) and the eukaryotic cassette with the gene of interest. During the event, the recombinase mediates the recombination between its recognition sequences, originating two circular, covalently closed molecules (i) the minicircle containing the eukaryotic cassette and (ii) a miniplasmid comprised of the prokaryotic backbone (Darquet et al., 1997).

The development of minicircle production systems has focused on increasing recombination efficiencies and minimizing multimeric forms by using different inducible recombinases from the tyrosine and serine families (Tyrosine family: $\lambda$-integrase (Darquet et al., 1997), Cre-recombinase (Bigger et al., 2001), FLP-recombinase (Nehlsen et al., 2006); Serine family: $\phi C 31$-integrase (Chen et al., 2003), ParA-resolvase [Jechlinger et al., 2004; Mayrhofer et al., 2008; Šimčíková et al., 2014]). Additionally, substantial efforts have been devoted to the development of production systems and strategies that deliver increased titers and facilitate the purification of the minicircle. The goal of this review is to address the several methodologies used for minicircle purification and their dependence on the selected upstream production strategy.

\section{PURIFICATION STRATEGIES}

The implementation of a minicircle purification strategy is highly dependent on the DNA mixture obtained after the lysis of cells collected at the end of bacterial growth. Unlike the typical pDNA production, in which two topological isoforms of the product are obtained (open circular and supercoiled), in minicircle production additional DNA species are obtained, which include the miniplasmid and residual un-recombined parental plasmid, with the corresponding topoisomers (Schleef et al., 2010; Mayrhofer and Iro 2012). This complicates minicircle purification since these other molecules display similar physicochemical properties. Additionally, minicircles and miniplasmids will usually have very similar sizes. The efficiency of the recombination process is especially critical in this context, since a complete recombination of parental plasmids will prevent contamination of minicircles with this DNA impurity.

When purifying conventional pDNA vectors, several types of chromatographic methods (e.g., hydrophobic interaction, anion exchange, multimodal, affinity) can be applied after primary isolation that are virtually independent of the upstream process used for production. Detailed overviews of chromatographic methods used for pDNA purification can be found in the following reviews (Diogo et al., 2005; Sousa et al., 2008a; Ghanem et al., 2013; Abdulrahman and Ghanem 2018). However, the direct application of these chromatographic methods to minicircle purification is usually ineffective since miniplasmids and parental plasmids will in general co-elute with minicircles (Mayrhofer and Iro 2012). Additional strategies must then be adopted that are usually applied in vivo, during minicircle 
TABLE 1 | Suggested specifications for pDNA-based vaccines and possible analytical methods (adapted from FDA - Center for Biologics Evaluation and Research, 2007; Schleef et al., 2010; Urthaler et al., 2012).

\begin{tabular}{|c|c|c|}
\hline Parameter & Analytical method & Suggested specifications \\
\hline \multicolumn{3}{|l|}{ Impurities } \\
\hline Proteins & BCA (bicinchoninic acid) assay, ELISA & $<1 \%$ \\
\hline RNA & Agarose gel electrophoresis, quantitative PCR, fluorescence assays (Ribogreen) & $<1 \%$ \\
\hline gDNA & Agarose gel electrophoresis, Southern blot, quantitative PCR & $<1 \%$ \\
\hline Endotoxins & LAL (Limulus Ameobocyte Lysate) assay & 40 EU/mg plasmid \\
\hline Microorganisms & Bioburden test, sterility test & $<1 \mathrm{CFU}$ \\
\hline \multicolumn{3}{|l|}{ Plasmid } \\
\hline Identity & Restriction enzyme mapping, DNA sequencing, immunological assays & Conformity to plasmid DNA map \\
\hline Homogeneity & Agarose gel electrophoresis, anion exchange-HPLC & $>80 \%$ supercoiled form \\
\hline Potency & Cell transfection & According to application \\
\hline
\end{tabular}

production, or implemented as an in vitro step that precedes the purification.

The purification strategy is not only crucial to isolate the molecule of interest, but also to obtain a product complying with the guidelines of regulatory agencies such as the FDA (Food and Drug Administration) and EMA (European Medicines Agency). Biopharmaceutical DNA products are expected to follow specific guidelines (Table 1) regarding the type and amount of impurities allowed in the final product (e.g., endotoxins, host cell proteins and genomic DNA (gDNA)) and the confirmation of DNA sequence, identity and integrity (FDA - Center for Biologics Evaluation and Research, 2007; EMA - Committee for Advanced Therapies, 2018).

Several process solutions have been reported in the last years that overcome the shortcomings of the first methods reported for minicircle purification (in vitro linearization followed by cesium chloride gradient centrifugation (Darquet et al., 1997; Bigger et al., 2001; Nehlsen et al., 2006) or agarose gel electrophoresis (Darquet et al., 1997)), which were neither suitable to obtain a clinical grade product nor allowed largescale purification (Darquet et al., 1997; Mayrhofer et al., 2008; Mayrhofer and Iro 2012). In general these process solutions usually include the alkaline lysis of cells, pre-purification steps and then chromatographic separations, which constitute the heart of the purification. This review provides an overview of processes used to purify minicircle vectors (see Figure 2), with a special focus on the strategies used to separate minicircles from miniplasmids and parental plasmids. The different methodologies are grouped according to the upstream strategy that is employed before the chromatographic step to enable its application for successful minicircle purification. The strategies explored are usually applied in vivo, during minicircle production, or implemented as an in vitro step prior to chromatographic purification.

\section{Purification Strategies Independent of Plasmid Restriction}

The first two cases discussed here deal with minicircle purification strategies that do not require degradation or topological modification of miniplasmid and parental plasmid impurities.

\section{Immobilization in Bacterial Ghosts}

An interesting strategy for minicircle purification was described by Jechlinger and co-workers in 2004 (Jechlinger et al., 2004), which consists of an in vivo process in E. coli that combines (i) parental plasmid recombination with the (ii) inducible anchoring of minicircle molecules into the inner membrane of bacterial cells, and (iii) with and inducible cell lysis to release cytoplasmatic material and miniplasmids. The resulting product is thus a preparation consisting of minicircles immobilized in bacterial ghosts, which are presented as safe for DNA delivery (Jechlinger et al., 2004). Briefly, bacterial ghosts are empty bacterial cell envelopes that are obtained by controlled expression of the cloned lysis gene $E$ of bacteriophage $\phi X 174$ which codes for a membrane protein. In Gram-negative bacteria, this protein oligomerizes into a transmembrane channel structure that lyses the cell and releases its cytoplasmatic content, without compromising the structural integrity of the cell envelope (Jechlinger et al., 2004; Langemann et al., 2010). More thorough explanations on bacterial ghosts and their use and applications (e.g., as adjuvants to boost immune responses, carriers of DNA vaccines and foreign protein antigens) can be found in the following reviews (Paukner et al., 2006; Langemann et al., 2010; Hajam et al., 2017). In the process under analysis (Jechlinger et al., 2004), the immobilization of minicircles on the bacterial ghosts is achieved by the in vivo expression of a lacI-L' hybrid gene that results in a LacI-L' fusion protein that integrates in the inner cell membrane. Minicircles harboring lac operator sites can thus bind to LacI (the repressor protein of the lactose operon) and are self-immobilized in the cell membrane. This strategy relies on the observation that repression of genes involved in the lactose metabolism is mediated via the interaction of the LacI protein with operators in the lac operon (Balaeff et al., 2004). The production of bacterial ghosts with immobilized minicircles is achieved in a single fermentation process with E. coli transformed with two plasmids that harbor all the necessary elements. The parental plasmid carries (i) lac operators in the region of the eukaryotic cassette, (ii) the recombinase gene needed to mediate parental plasmid intramolecular recombination, and (iii) the lacI-L' hybrid gene, being the last two located in the prokaryotic backbone under the control of an L-arabinose inducible promoter. An additional plasmid containing the gene $E$ of bacteriophage $\phi X 174$ under the control of a thermo-inducible promoter was also co- 


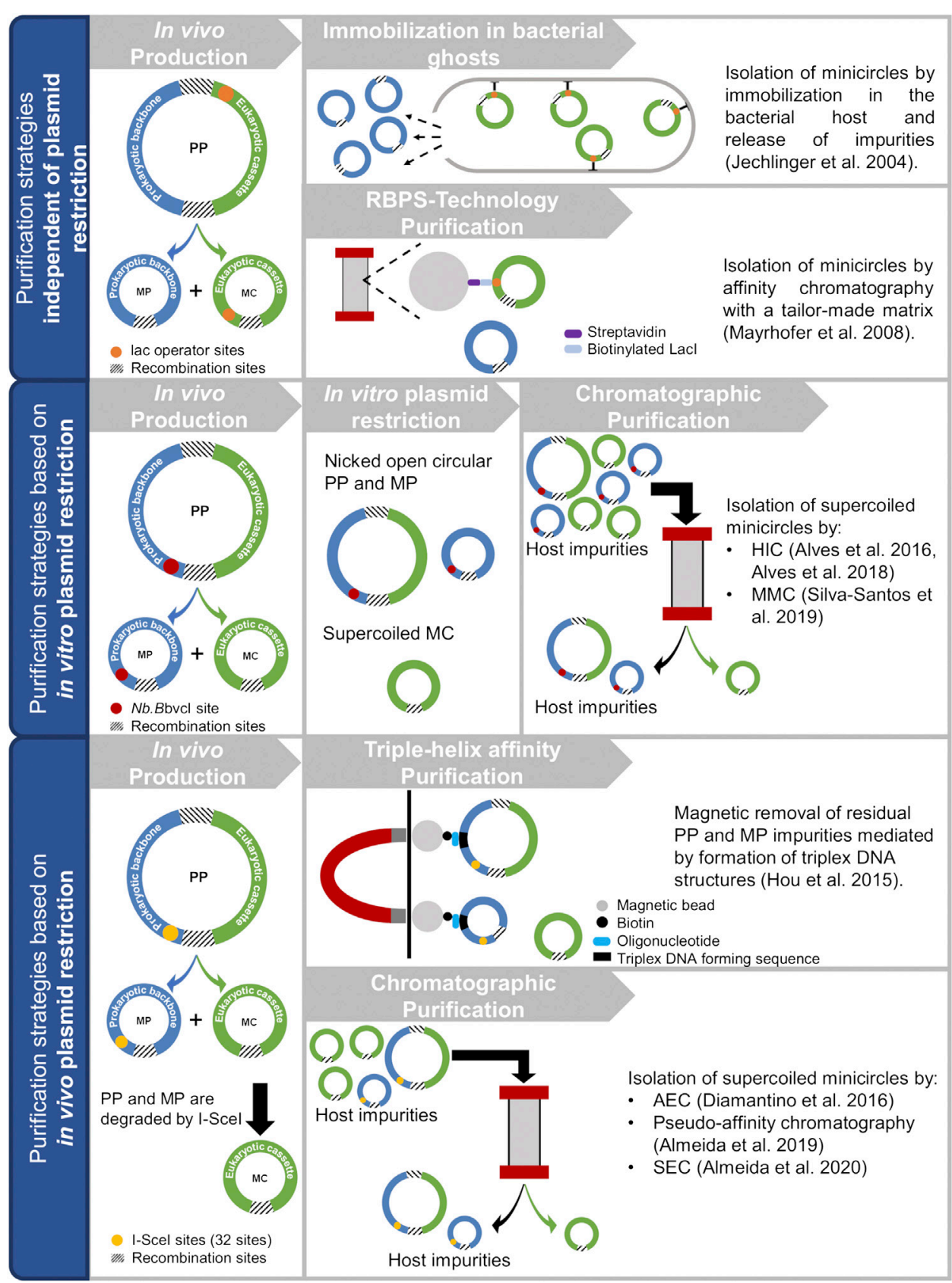

FIGURE 2 |Schematic and summarized representation of the strategies used for minicircle purification. PP, parental plasmid; MP, miniplasmid; MC, minicircle; HIC, hydrophobic interaction chromatography; MMC, multimodal chromatography; AEC, anion exchange chromatography; SEC, size-exclusion chromatography.

transformed into the cells. During bacterial growth, recombination and expression of the LacI-L' fusion protein were induced by supplementing the medium with $0.5 \%$ $\mathrm{L}$-arabinose. The culture was further subjected to a temperature shift from 36 to $42^{\circ} \mathrm{C}$ to induce the expression of protein $\mathrm{E}$ and, consequently, cell lysis. Analysis of culture supernatants and cell pellets confirmed that minicircle immobilization is successful, albeit a small amount of $10 \%$ is lost due to release from the cells after lysis. However, bacterial ghosts present a mixture of the two recombination products, with $30 \%$ in miniplasmid impurities. As the authors suggested, this can be improved by the inclusion of in vivo degradation of miniplasmid molecules, to increase minicircle purity in the final sample (Jechlinger et al., 2004). Since parental plasmids also contain lac operator sites in the eukaryotic cassette, a complete recombination of parental plasmids is also crucial to 
avoid their co-immobilization on the bacterial ghosts. Overall, bacterial ghost DNA carriers could be of special relevance for minicircle-based vaccines in which the triggering of the immune system is a desired therapeutic outcome.

\section{Recombination Based Plasmid Separation Technology}

Some researchers have attempted to develop affinity chromatographic purification protocols based on the selective and reversible interaction between pDNA and a ligand present on stationary matrix, as described in the following reviews (Diogo et al., 2005; Ghanem et al., 2013; Abdulrahman and Ghanem 2018). In 2008 Mayrhofer and co-workers adapted affinity chromatography for minicircle purification (Mayrhofer et al., 2008). The strategy developed, which the authors termed 'Recombination Based Plasmid Separation Technology' (RBPSTechnology), is performed after in vivo plasmid recombination and relies on the use of a matrix modified with the LacI protein and its interaction with lactose operator sites in the DNA molecules. Similar strategies had been previously applied for purification of pDNA containing lac operators (Darby and Hine 2005; Hasche and Voß 2005; Forde et al., 2006) and also of minicircles, as described above (Jechlinger et al., 2004). In their work, Mayrhofer et al. (2008) designed the parental plasmid to harbor a tandem repeat of a symmetric version of the lactose operator sites (LacOs) on the eukaryotic cassette region. The base for the affinity chromatographic matrix is a resin carrying covalently bound tetrameric streptavidin-Streptavidin Sepharose High Performance-on which a biotinylated LacI protein was immobilized via biotin/streptavidin interaction. Binding and elution studies were performed with this matrix and with plasmids with and without LacOs sites to evaluate the ionic strength needed in the mobile phase to avoid binding of unspecific pDNA. While unspecific binding occurred at low $\mathrm{NaCl}$ concentrations it could be avoided by using $400 \mathrm{mM} \mathrm{NaCl}$ in the mobile phase. Elution conditions were tested that relied on a $\mathrm{NaCl}$ step gradient from $10 \mathrm{mM}$ to $1 \mathrm{M} \mathrm{NaCl}$ with a constant concentration of $5 \mathrm{mM}$ of isopropyl $\beta$-D-1-thiogalactopyranoside (IPTG). Since IPTG is able to bind to LacI promoting the dissociation of the LacI-lac operator complexes, it should thus lead to the release of LacOs-bearing pDNA molecules (Jobe and Bourgeois 1972; Darby and Hine 2005). In this case, it was observed that the presence of IPTG decreased the amount of $\mathrm{NaCl}$ needed to elute nonspecific pDNA, showing the capability of these molecules to interact with nonspecific binding sites and thus decreasing the matrix capacity. Large-scale minicircle purification was performed with a column packed with $5 \mathrm{~mL}$ of matrix connected to an ÄKTA system. Column equilibration and sample injection (minicircles and miniplasmids) were performed with $400 \mathrm{mM} \mathrm{NaCl}$ in $50 \mathrm{mM}$ Tris (pH 8). Following column washing with the same mobile phase, minicircle elution was achieved with a buffer containing $500 \mathrm{mM} \mathrm{NaCl}$ and $5 \mathrm{mM}$ IPTG in $50 \mathrm{mM}$ Tris (pH 8). Quality assays confirmed that the final minicircle was essentially found in the supercoiled form (98.9\%) and that gDNA, RNA, endotoxin and protein content were within the recommended by regulatory agencies for pDNA vaccines preparations. Quantitative PCR analysis further showed the presence in the final minicircle of 1 and $0.2 \%$ of, respectively, parental plasmid and miniplasmid impurities (Mayrhofer et al., 2008).

Although minicircle purification was successful and the process is expected to be easily scalable, its use for purification of pharmaceutical grade material will require extensive validation and regulatory evaluation due to its novelty (Mayrhofer et al., 2008). Moreover, LacOs sites must be incorporated whenever a new eukaryotic cassette is designed and will always be a part of the final minicircle molecule. Nevertheless, a collaboration with BIA Separations was announced in 2018 that aims to combine this company's monolithic supports with RBPS technology to achieve a clinical-scale production of minicircles (BIA Separations 2018). ${ }^{2}$

\section{Purification Strategies Based on in vitro Plasmid Restriction}

The methods described below rely on the in vivo production of minicircles via intramolecular recombination of a parental plasmid followed by isolation and then an in vitro restriction step. The in vitro restriction of miniplasmids and residual un-recombined parental plasmids is performed using a nicking endonuclease $(\mathrm{Nb} \cdot \mathrm{BbvCI})$ that cuts only one of the strands of the double helix at the recognition site (Heiter et al., 2005). The parental plasmid was designed to harbor a recognition site for this enzyme on the prokaryotic backbone. This ensures that only miniplasmids and parental plasmid will be targeted and converted from the supercoiled isoform into the corresponding open circular isoforms, while the minicircle supercoiled topology will remain unaltered (Heiter et al., 2005; Alves et al., 2016). This selective modification of the topology of the miniplasmid and parental plasmid impurities makes it then possible to explore chromatographic techniques that can separate supercoiled from open circular DNA molecules. Below are described the two cases that have been reported using this in vitro topological modification.

\section{Hydrophobic Interaction Chromatography}

Hydrophobic interaction chromatography (HIC) is a commonly used operation in pDNA purification from clarified lysates, which takes advantage of the lower hydrophobicity of pDNA when compared with gDNA, RNA and endotoxin impurities (Prazeres 2011). In this type of chromatography, sample injection and stationary matrix equilibration are typically performed at high concentration of a kosmotropic salt (e.g., ammonium sulfate, sodium citrate) to assure that hydrophobic interactions occur between the ligands in the matrix and the hydrophobic molecules in the mobile phase, being these retained in the column (Prazeres 2011). Thus, at high ionic strengths (e.g., $1.5 \mathrm{M}$ ammonium sulfate), pDNA does not interact with the matrix and is eluted

${ }^{2}$ https://www.biaseparationscom/en/news-events/news/127/bia-separationspartnerswith-rbps-technology-to-provide-large-scale-minicircle-dna-vectorproduction 
in the flowthrough. Hydrophobic impurities, on the other hand, are retained and will only elute by decreasing salt concentration (Diogo et al., 2000; Freitas et al., 2009). This type of chromatography can successfully separate pDNA isoforms by further increasing the ionic strength of the mobile phase during loading (Urthaler et al., 2005; Freitas et al., 2009; Bo et al., 2013). This has been attributed to a higher exposure of the hydrophobic bases in supercoiled isoforms as a consequence of torsional strain, a phenomenon that does not occur in open circular DNA. This higher exposition can be exacerbated at high salt concentrations, leading to the establishment of interactions between the matrix ligands and supercoiled DNA species (Freitas et al., 2009; Prazeres 2011; Bo et al., 2013).

In the proof of concept presented by Alves and co-workers (Alves et al., 2016; Alves et al., 2018), the use of a mobile phase with high ammonium sulfate concentration enabled a successful minicircle isolation by HIC. In addition to the typical unit operations used before HIC (cell lysis, isopropanol precipitation of nucleic acids and ammonium sulfate precipitation of proteins), this method also includes sample desalting and concentration to allow the nicking of unrecombined parental plasmid and miniplasmid in an in vitro enzymatic reaction before sample injection $(1 \mathrm{~mL})$ into a $10 \mathrm{~mL}$ column packed with Phenyl Sepharose 6 Fast Flow. To allow the interaction of supercoiled minicircles with the matrix, the sample was conditioned with up to $2.5 \mathrm{M}$ ammonium sulfate and column was equilibrated with $1.83 \mathrm{M}$ ammonium sulfate in $10 \mathrm{mM}$ Tris- $\mathrm{HCl}, 1 \mathrm{mM}$ EDTA (pH 8) (Alves et al., 2016; Alves et al., 2018). During column washing, complete elution of open circular isoforms of both miniplasmid and minicircle was observed. Bound supercoiled minicircles were then eluted by a stepwise decrease of ionic strength to $1.43 \mathrm{M}$ ammonium of ammonium sulfate and, finally, strongly bound RNA was eluted by complete removal of ammonium sulfate from the mobile phase. Processing of a similar sample that was not subjected to enzymatic restriction yields a fraction containing supercoiled minicircles but also supercoiled miniplasmids. This confirms that strand nicking of miniplasmids is critical to obtain pure minicircles (Alves et al., 2016). The method was found to be reproducible and robust, and was successfully applied to the purification of three different minicircle molecules, which were obtained virtually free from parental plasmid, miniplasmid and RNA impurities. Although the levels of gDNA were slightly above the recommended by regulatory agencies for $\mathrm{pDNA}$ vaccines showing that slight adjustments in the method are needed, proteins were undetected (Alves et al., 2016). This indicates that the nicking endonuclease used in vitro does not co-elute with supercoiled minicircle molecules. The main drawbacks of the method are the cost associated with using the nicking enzyme in a scale compatible with biopharmaceuticals production and an increased duration of the process length due to the high number of unit operations needed (Alves et al., 2016; Alves et al., 2018). However, the stationary matrix used is commercially available, which can reduce process costs and enzyme restriction sites are located on the prokaryotic backbone thus posing no constraint on the minicircle molecule. Different minicircles can thus be obtained by modifying only the eukaryotic region of the parental plasmid without impacting the purification strategy.

\section{Multimodal Chromatography}

Multimodal chromatography (MMC)-also termed mixed mode chromatography-is characterized by the use stationary matrices harboring ligands able to establish multiple types of interaction (e.g., electrostatic/hydrophobic, hydrophobic/ hydrogen bonding) with solutes present in the mobile phase (Zhao et al., 2009; Kallberg et al., 2012; Abdulrahman and Ghanem 2018). This results in a highly versatile chromatographic media that allows the use of multiple interactions to purify the desired molecule. The type and strength of different solute/matrix interactions can thus be modulated in a single operational unit using variations of the mobile phase (Kallberg et al., 2012; Abdulrahman and Ghanem 2018; Halan et al., 2019). MMC is considered a cost-effective technique with high throughput and increased selectivity (Kallberg et al., 2012; Zang and Liu 2016; Halan et al., 2019). Also, given the wide range of possible interaction combinations, it can be virtually applied to any separation of biomolecules (Kallberg et al., 2012; Halan et al., 2019).

MMC has been successfully applied for pDNA purification (Matos et al., 2013; Černigoj et al., 2013; Silva-Santos et al., 2016; Silva-Santos et al., 2017) due to its ability to selectively fractionate pDNA isoforms (Černigoj et al., 2013; Silva-Santos et al., 2017). More recently, Silva-Santos et al. reported the use of MMC for supercoiled minicircle purification after in vitro nicking of miniplasmids and residual un-recombined parental plasmid (Silva-Santos et al., 2019), by using a method previously established by the authors for pDNA isoform isolation (SilvaSantos et al., 2017). The method relies on sequential precipitations (isopropanol, ammonium acetate and PEG$8000)$ to remove impurities and precipitate nucleic acids from clarified lysates, followed by in vitro enzymatic restriction. Digested sample was then subjected to MMC in a column packed with $5 \mathrm{~mL}$ of a resin modified with N-benzyl-N-methyl ethanolamine ligands (Capto ${ }^{\mathrm{TM}}$ adhere). Column equilibration, sample injection and column washing were performed at mild ionic strength $(830 \mathrm{mM} \mathrm{NaCl}$ in $10 \mathrm{mM}$ Tris- $\mathrm{HCl}, 1 \mathrm{mM}$ EDTA, $\mathrm{pH} 8$ ), followed by a stepwise elution strategy at $920 \mathrm{mM}$ and $2 \mathrm{M}$ $\mathrm{NaCl}$. The results obtained show that open circular isoforms do not bind to the matrix and are eluted in the flowthrough, while supercoiled minicircle is eluted by increasing $\mathrm{NaCl}$ to $920 \mathrm{mM}$ $\mathrm{NaCl}$ and strongly bond RNA is eluted latter at $2 \mathrm{M}$. The method was robust and reproducible, allowing $30 \mu \mathrm{g}$ of supercoiled minicircle to be recovered with a homogeneity $>90 \%$ from a $100 \mu \mathrm{g}$ feed containing miniplasmid impurities (Silva-Santos et al., 2019). According to the previous work describing supercoiled pDNA purification by MMC (Silva-Santos et al., 2017), the full process should promote removal of gDNA and proteins to levels accepted by regulatory agencies. However, the method should be evaluated to confirm if recovery yields and product quality similar to the ones reported for supercoiled pDNA isolation can be obtained. 
Further analysis of the separation obtained with the MMC CaptoAdhere column (Silva-Santos et al., 2019) provided interesting insights into the interactions at play between the DNA molecules and the multimodal ligands. The CaptoAdhere ligands allow the establishment of electrostatic, hydrophobic and hydrogen bond interactions (Silva-Santos et al., 2019). Control experiments showed that neither hydrophobic nor electrostatic interactions alone could explain the elution profiles obtained under the conditions used in MMC. Rather, it was hypothesized that elution behavior of the different DNA species results from a combination of electrostatic, cation- $\pi$, $\pi-\pi$ stacking and hydrogen bonding interactions between the ligand and the phosphate and base groups of the nucleic acids (Silva-Santos et al., 2019).

\section{Purification Strategies Based on in vivo Plasmid Restriction}

The pursue for better producer of minicircles led to the development of E. coli ZYCY10P3S2T, a strain that harbors in its genome two inducible systems to express (i) a recombinase that drives intramolecular recombination of the parental plasmid into minicircle and miniplasmid, and (ii) the I-SceI endonuclease that promotes degradation of miniplasmids and un-recombined parental plasmid after recombination (Kay et al., 2010). This last characteristic is of special relevance for minicircle purification purposes, as during the production step two important impurities - the residual un-recombined parental plasmid and the miniplasmid-are degraded. Their presence is thus greatly reduced even before the start of isolation and purification. Although both systems are under the control of the same L-arabinose inducible promoter, the number of copies of each one of them was optimized to assure that, upon induction, minicircle was produced before the onset of parental plasmid degradation (Kay et al., 2010). This is especially relevant to prevent parental plasmid loss prior to recombination and thus avoid losses on minicircle production yield. The minicircle purification strategies applied after this production scheme are discussed below.

\section{Triple-Helix Affinity Purification}

Formation of triple helix DNA structures occurs via the binding of a single stranded DNA molecule in the major groove of double stranded DNA. Triple helix formation takes advantage of the reversible hybridization, through Hoogsteen hydrogen bonds, between poly-pyrimidine oligonucleotides and poly-purine sequences in the target double stranded DNA molecule. As protonation of cytosine is a requirement for the formation of the triple helix, buffers used during hybridization are typically mildly acidic to favor hydrogen bonds, whereas triple helix can be destabilized and disassociated in alkaline conditions (Wils et al., 1997; Schluep and Cooney 1998; Costioli et al., 2001; Prazeres 2011; Hou et al., 2015). This principle has been used for purification of pDNA by linking oligonucleotides, for example, to a chromatographic matrix (Wils et al., 1997; Schluep and Cooney 1998) or to a stimulus-responsive polymer that could be precipitated by a temperature shift (Costioli et al., 2001).
A report by Hou and co-workers describes the application of the triple-helix affinity principle to the purification of minicircle molecules (Hou et al., 2015). To enable triple helix formation, the prokaryotic backbone of the parental plasmid was designed to harbor poly-purine sequences. After minicircle production in E. coli ZYCY10P3S2T and DNA pre-purification with a commercial kit, the minicircle DNA-containing sample was mixed with biotinylated oligonucleotides and streptavidincoated magnetic beads. In this mixture, the biotinylated oligonucleotide forms a triple helix with parental plasmid and miniplasmid species and the resulting complexes are captured by the binding to the magnetic particles via biotin/streptavidin interaction. The triple helix formation and magnetic capture is promoted in a mildly acidic buffer ( $\mathrm{pH} 4.5)$ and under gentle agitation. After incubation, a magnet is used to separate the impurity-loaded magnetic particles from the minicirclecontaining supernatant. The minicircle is then removed from the supernatant with ethanol precipitation and resuspended in an appropriate buffer. For improved purification, several parameters were evaluated: (i) influence of the length of the triple helix forming sequences, (ii) sample conditioning with variable amounts of parental plasmid impurities, and (iii) influence of parental plasmid size (Hou et al., 2015). It was observed that length of triple helix forming sequences and parental plasmid impurities in the final minicircle product presented an inverse correlation, although in all cases the parental plasmid content was brought to levels below the required by regulatory agencies. The method showed also to be suitable for the removal of parental plasmid impurities comprising up to $10 \%$ of the initial sample to be purified. In the range of parental plasmid size tested (up to $9 \mathrm{kbp}$ ), the purification method could produce a final product with about $0.03 \%$ in parental plasmid impurities (Hou et al., 2015). Although the cost of streptavidin beads is high, the authors were able to recycle them making the process more affordable. Also, the use of a commercial kit for pre-purification of the bacterial lysate allowed to reduce by $95 \%$ the amount of beads needed, rendering the process more cost-effective (Hou et al., 2015). However, unit operations that could replace the use of the commercial kit would probably be advisable for the application of triple-helix separation in industrial scale purification of minicircle.

\section{Anion Exchange Chromatography}

Anion-exchange has been extensively used for pDNA chromatographic purification [e.g., (Eon-Duval and Burke 2004; Quaak et al., 2008; Bakker et al., 2019)]. The choice for this type of chromatography to purify pDNA from a solution containing impurities such as gDNA, RNA and proteins, which result from bacterial lysis and intermediate recovery, is due to the different charge densities presented by these molecules. In anion exchange chromatography (AEC), the pDNA separation is promoted by the interaction between the negatively charged phosphate groups in DNA and the anionic ligands in the chromatographic matrix. Typically, pDNA-containing solutions are loaded onto the chromatographic column at concentrations of $\mathrm{NaCl}$ high enough $(\approx 500 \mathrm{mM})$ to avoid the binding of impurities with lower charge density than pDNA (e.g., 
proteins and RNA with low-molecular weight), which are washed-out in the flowthrough. Bound species can then be eluted by increasing the salt concentration of the mobile phase. In this step, selective elution can be successfully achieved by using an increasing gradient or stepwise elution with increasing concentrations that disrupt the electrostatic interactions between the molecules and the ligands on the stationary phase. The strength of these interactions is dependent on the molecule size since longer molecules present a higher charge density. Thus, the elution profile will reflect this size-dependent molecule displacement with RNA being eluted before pDNA (Prazeres 2011; Ghanem et al., 2013; Abdulrahman and Ghanem 2018). However, co-elution of pDNA, RNA and gDNA is a recurrent problem in AEC being of special interest to assure that, during the lysis steps, gDNA is not fragmented into pieces with a similar size to pDNA to avoid co-elution (Prazeres 2011). Topology of DNA can also affect interaction with the matrix, with supercoiled pDNA being eluted after open circular due its apparent smaller size and higher charge density induced by the torsional strain in this isoform (Prazeres 2011). This aspect has been explored for the purification of supercoiled pDNA (e.g., (Prazeres et al., 1998; Quaak et al., 2008; Li et al., 2011)).

A study conducted by Diamantino and co-workers (Diamantino et al., 2016) employed a CIM ${ }^{\circledR}$ DEAE-1 monolithic column to purify minicircle DNA and to isolate its supercoiled isoform. The method developed is reproducible and allows the isolation of supercoiled minicircle from impurities resulting from production in E. coli (RNA, gDNA, proteins and endotoxins) and from the in vivo recombination (parental plasmid and miniplasmid). Minicircle production was accomplished in E. coli ZYCY10P3S2T, which greatly reduces the content of parental plasmid and miniplasmid impurities due to the action of the I-SceI endonuclease. The chromatographic method presented by Diamantino and co-workers (Diamantino et al., 2016) was applied after alkaline lysis of bacterial cells and lysate clarification by precipitation with $2 \mathrm{M}$ of ammonium sulfate to reduce the RNA and protein content. The resulting solution was then subjected to AEC using a $\mathrm{CIM}^{\circledR}$ DEAE-1 monolithic column (BIA Separations) with $1 \mathrm{~mL}$ of bed volume. The loading and elution strategies were optimized in this work to (i) minimize retention of impurities in the column that would co-elute with minicircles, (ii) allow the selective elution of open circular and supercoiled isoforms, and (iii) allow the separation between supercoiled parental plasmid and minicircle. To maximize the removal of impurities in the flowthrough, the volume of sample loaded was kept at $100 \mu \mathrm{L}$. The optimized method for supercoiled minicircle isolation consisted on column equilibration and washing with $0.71 \mathrm{M}$ $\mathrm{NaCl}$ in $50 \mathrm{mM}$ Tris- $\mathrm{HCl}(\mathrm{pH}$ 8) followed by a 15 min linear gradient up to $0.75 \mathrm{M} \mathrm{NaCl}$ in $50 \mathrm{mM}$ Tris- $\mathrm{HCl}(\mathrm{pH} 8)$ and a final step at $1 \mathrm{M} \mathrm{NaCl}$ for the elution of strongly bound species. The results obtained show successful supercoiled minicircle isolation at the end of the linear gradient, despite some losses during column washing and in late eluting peaks where it is co-eluted with open circular isoforms and parental plasmid impurities. The separation of parental plasmid and minicircle can be explained by the differences in size of the minicircle $(3.06 \mathrm{kbp})$ and of the parental plasmid $(7.06 \mathrm{kbp})$. In addition, the authors measured the zeta potential of these two molecules, which confirmed that the minicircle is less negatively charged and should thus elute before parental plasmid (PP: $-32.63 \pm 0.25 \mathrm{mV}$; MC: $-8.59 \pm$ $0.07 \mathrm{mV}$ ). The optimized method is a $30 \mathrm{~min}$ chromatographic run that isolates pure supercoiled minicircle complying with FDA requirements for impurities (gDNA, proteins and endotoxins) content (Diamantino et al., 2016). However, the method is characterized by a low recovery yield of supercoiled minicircle of $50 \%$, as mentioned by the authors on a latter study (Almeida et al., 2019).

\section{Pseudo-Affinity Chromatography}

Pseudo-affinity interactions between nucleic acids in the mobile phase and a stationary matrix have been previously explored for the chromatographic purification of pDNA [e.g., (Sousa et al., 2006; Sousa et al. 2008b; Sousa et al. 2009)]. This strategy addresses some of the main drawbacks of other chromatographic methods, namely the lack of selectivity between pDNA molecules and impurities present in pDNAcontaining solutions, which hinder successful pDNA isolation in a single chromatographic operation (Sousa et al., 2009). The evidence that interactions between proteins and DNA molecules is mediated via amino acid residues and nucleotides on the DNA chain (Luscombe et al., 2001; Hoffman et al., 2004) led researchers to explore this characteristic to develop new ligands for chromatographic matrices. The forces at play in these interactions at atomic level include van der Waals and hydrophobic contacts, water-mediated bonds, cation- $\pi$ and electrostatic and stacking interactions, as well as hydrogen bonding which was found to be the largest contributor to specific recognition of pDNA (Luscombe et al., 2001; Hoffman et al., 2004; Sousa et al., 2010). In addition, pDNA topology plays an important role, since nucleotide bases in supercoiled isoforms are more available for interaction than bases in open circular isoforms. This renders amino acid ligands-especially basic amino acids arginine, lysine and histidine-good candidates for supercoiled pDNA specific recognition and purification (Sousa et al., 2006; Sousa et al. 2008b; Sousa et al. 2009; Sousa et al. 2010). Recently two monolithic supports (CIM ${ }^{\circledR}$ epoxy monoliths from BIA Separations) were modified with either lysine or cadaverine (a decarboxylated derivative of lysine) ligands and used to isolate supercoiled minicircles by taking advantage of the pseudo-affinity principle (Almeida et al., 2019). Lysine was able to separate pDNA isoforms under mild salt conditions, by specifically recognizing and interacting with the supercoiled isoform through electrostatic interactions (Sousa et al., 2009; Almeida et al., 2019). In this work, production was conducted using E. coli ZYCY10P3S2T for combined minicircle generation and un-recombined parental plasmid and miniplasmid degradation, followed by bacteria alkaline lysis and subsequent desalting to obtain the clarified lysate (Almeida et al., 2019). In the case of the lysine monolith, the optimized protocol consisted on the injection of $100 \mu \mathrm{L}$ of lysate at $190 \mathrm{mM} \mathrm{NaCl}$ in $10 \mathrm{mM}$ Tris- $\mathrm{HCl}$ (pH 7.0) into a $100 \mu \mathrm{L}$ monolith pre-equilibrated with the same buffer. Following washing, which mainly removed RNA, supercoiled MC was 
recovered by increasing the buffer ionic strength to $240 \mathrm{mM} \mathrm{NaCl}$ in $10 \mathrm{mM}$ Tris- $\mathrm{HCl}(\mathrm{pH}$ 7.0). However, the amount of supercoiled minicircle recovered in this step was very low when compared to what was co-eluted with open circle minicircle and both isoforms of parental plasmid in the final step at $1 \mathrm{M} \mathrm{NaCl}$ in $10 \mathrm{mM}$ Tris-HCl (pH 7.0). Further optimization was attempted but only a small improvement on supercoiled minicircle recovery was observed and its purity decreased. The poor selectivity of the lysine ligand in the context of supercoiled minicircle purification is related to the fact that parental plasmid and minicircle molecules share similar properties (Almeida et al., 2019).

Cadaverine ligands were explored for minicircle purification in an attempt to minimize the repulsion between the carboxyl group in lysine and phosphate groups, and hence increase the binding strength between the ligand and supercoiled minicircles. When both monoliths were subjected to the same gradient conditions, elution peaks resulting from the cadaverine monolith were observed at latter times. The fact that a higher ionic strength in the mobile phase is needed to disrupt the ligandmolecule interaction indicates that the cadaverine ligand is involved in stronger electrostatic interactions with the molecules in the clarified lysate. The conditions optimized for minicircle purification consisted in the injection of a clarified lysate at $1.07 \mathrm{M} \mathrm{NaCl}$ in $10 \mathrm{mM}$ Tris- $\mathrm{HCl}(\mathrm{pH} 7.0)$ into the cadaverine monolith equilibrated at the same salt concentration. RNA was removed during washing, whereas the supercoiled minicircle was recovered by a stepwise increase on the mobile phase ionic strength to $1.16 \mathrm{M} \mathrm{NaCl}$ in $10 \mathrm{mM}$ Tris- $\mathrm{HCl}$ (pH 7.0). Elution of strongly bound impurities-such as parental plasmid and gDNA - was achieved by a second stepwise increase to $1.3 \mathrm{M}$ $\mathrm{NaCl}$ in $10 \mathrm{mM}$ Tris- $\mathrm{HCl}$ ( $\mathrm{pH} 7.0$ ). The supercoiled minicircle recovery yield and purity were 78.6 and $98.4 \%$, respectively. Importantly, the recovered minicircle fractions complied with the specifications regarding gDNA, proteins, RNA and endotoxins content (Almeida et al., 2019). Thus, and in spite of the use of high $\mathrm{NaCl}$ concentration, the cadaverine modified monolith successfully purified supercoiled minicircle preparations in a low-cost and simple chromatographic approach.

\section{Size Exclusion Chromatography}

In size-exclusion chromatography (SEC), biomolecules are sequentially eluted depending on the path followed through the chromatographic matrix, with smaller molecules eluting later than larger molecules (Diogo et al., 2005; Prazeres 2011). In the case of pDNA purification, SEC is typically applied as a polishing step after other chromatographic methods to desalt samples, exchange buffer and remove impurity traces (Ferreira et al., 2000; Urthaler et al., 2005; Prazeres 2011; Ghanem et al., 2013; Abdulrahman and Ghanem 2018). SEC has also been used to fractionate pDNA isoform (Li, et al., 2007; Latulippe and Zydney 2009). Regarding the elution profile and/or molecule co-elution, it will depend on several operating parameters such as the fractionation range of the matrix chosen-i.e., the exclusion limit for the size of molecules that can enter the matrix pores-and salt type and concentration on the mobile phase (which can affect the shape and conformation of nucleic acids, thus altering their apparent size). Several cases have been examined in the following reviews (Ferreira et al., 2000; Diogo et al., 2005; Prazeres 2011; Ghanem et al., 2013; Abdulrahman and Ghanem 2018).

A work developed by Almeida et al. (2020a) successfully took advantage of SEC in the isolation of supercoiled minicircles. The strategy applied for minicircle production involved the use of the same ZYCY10P3S2T E coli strain, meaning that miniplasmid and parental plasmid impurities are greatly reduced during the production step. Following intermediate recovery, the lysate sample was directly injected into a chromatographic column, with a diameter of $1.6 \mathrm{~cm}$ and a bed height of $60 \mathrm{~cm}$, connected to an AKTA Püre system and operated in isocratic mode with $150 \mathrm{mM} \mathrm{NaCl}$ in $10 \mathrm{mM}$ Tris- $\mathrm{HCl}, 10 \mathrm{mM}$ EDTA (pH 7.0) (Almeida et al., 2020a). The chromatographic separation in this work was achieved with Sephacryl S-1000 SF resin, a matrix widely used for SEC of pDNA [several works are reported in (Diogo et al., 2005)] and that has previously been used to study pDNA elution behavior in SEC depending on its size and topology (Latulippe and Zydney 2009). This matrix is characterized by an exclusion limit for DNA high enough (12 kbp for linear DNA and $400 \mathrm{~nm}$ for spherical particles) to allow its separation from high molecular weight RNA molecules, given that the latter is not excluded and can enter the pores of the resin beads (Diogo et al., 2005; Prazeres 2011). Thus, separation profiles with fractionation of (i) gDNA, (ii) open circular pDNA, (iii) sc pDNA and (iv) RNA and proteins can be achieved (Diogo et al., 2005; Prazeres 2011). In their work, Almeida and co-workers (Almeida et al., 2020a) optimized several parameters-flow-rate $(0.45$ and $0.3 \mathrm{~mL} / \mathrm{min})$, sample injection ( 4 and $2 \mathrm{~mL}$ ) and fraction volume (4 and $3 \mathrm{~mL}$ )-in order to achieve the desired supercoiled minicircle isolation with an optimal recovery yield and purity. The flow-rate in SEC has been associated with effects on molecule diffusion into and out of the matrix pores, being that lower flow-rates promote diffusion what in turn results in higher peak resolution. Volume of sample injection will have influence on the amount of impurities present in the chromatographic matrix, being inversely correlated with peak resolution. Finally, regarding the fraction volume collected, this parameter was studied to evaluate sample concentration and purity (Almeida et al., 2020a), as SEC does not involve a binding-elution mode and thus is associated with sample dilution. The best results were obtained for injections of $2 \mathrm{~mL}$ in chromatographic runs at $0.3 \mathrm{~mL} / \mathrm{min}$ with the recovery of $3 \mathrm{~mL}$ fractions. In these conditions, a $3.8 \mathrm{kbp}$ minicircle was successfully purified with a recovery yield and purity around 66 and 98\%, respectively. Also, the content on gDNA, RNA, proteins and endotoxins was found to be in compliance with regulatory guidelines for pDNA products. However, method optimization and application is dependent on the minicircle size, having been the aforementioned conditions not suitable to purity a second larger minicircle $(5 \mathrm{kbp})$ from its parental plasmid $(8.2 \mathrm{kbp})$ impurity (Almeida et al., 2020a).

Regarding molecules with higher sizes, the separation could be further hampered due to their lower ability to diffuse in the matrix pores, which can result in co-elution with molecules of higher size such as gDNA (Almeida et al., 2020a) and impossibility of isoform isolation (Latulippe and Zydney 2009). 
TABLE 2 | Summary analysis of strategies for purification of minicircle biopharmaceuticals.

\begin{tabular}{|c|c|c|c|}
\hline Purification strategy & Strain and/or parental plasmid characteristics & Purification support & Product purity \\
\hline $\begin{array}{l}\text { Immobilization in bacterial ghosts } \\
\text { Jechlinger et al. (2004) }\end{array}$ & $\begin{array}{l}\text { The eukaryotic cassette of the PP harbors the } \\
\text { recombinase gene (parA), the lacl-L' hybrid } \\
\text { gene and lac operator sites } \\
E \text {. coli co-transformation with helper plasmid for } \\
\text { expression of lysis gene } E\end{array}$ & Bacterial host cell envelope & $\begin{array}{l}\text { Bacterial cell envelopes containing } 70 \% \text { of } \\
\mathrm{MC} \text { and } 30 \% \text { of MP impurities }\end{array}$ \\
\hline $\begin{array}{l}\text { RBPS-technology purification } \\
\text { Mayrhofer et al. (2008) }\end{array}$ & $\begin{array}{l}\text { PP harbors the recombinase gene (parA) in the } \\
\text { prokaryotic backbone and lac operator sites in } \\
\text { the eukaryotic cassette }\end{array}$ & Non-commercial & $\begin{array}{l}\text { 98.9\% supercoiled MC } \\
\text { 1\% PP and } 0.2 \% \text { MP impurities } 0.05 \% \\
\text { gDNA; endotoxins } 0.4 \text { EU/mg pDNA, <1\% } \\
\text { host cell proteins, undetectable RNA }\end{array}$ \\
\hline $\begin{array}{l}\text { Hydrophobic interaction } \\
\text { chromatography Alves et al. (2016), } \\
\text { Alves et al. (2018) }\end{array}$ & $\begin{array}{l}\text { E. coli strain engineered with a copy of the } \\
\text { recombinase (parA) } \\
\text { expression system }\end{array}$ & Commercially available & $\begin{array}{l}\text { Visually undetectable PP, MP and RNA. } \\
1.6 \% \text { gDNA }\end{array}$ \\
\hline $\begin{array}{l}\text { Multimodal chromatography } \\
\text { Silva-Santos et al. (2019) }\end{array}$ & $\begin{array}{l}\text { Nicking endonuclease } \mathrm{Nb} . \mathrm{Bbvcl} \text { recognition } \\
\text { sites located in the prokaryotic backbone of PP }\end{array}$ & & $\begin{array}{l}\text { MC recovery of } \approx 30 \mu \mathrm{g} \text { per } 100 \mu \mathrm{g} \text { of } \mathrm{PP}, \mathrm{MP} \\
\text { and } \mathrm{MC} .>90 \% \text { supercoiled } \mathrm{MC} \\
\text { Visually undetectable } \mathrm{PP}, \mathrm{MP} \text { and } \mathrm{RNA}\end{array}$ \\
\hline $\begin{array}{l}\text { Triple-helix affinity chromatography } \\
\text { Hou et al. (2015) }\end{array}$ & $\begin{array}{l}\text { Commercially available E. coli ZYCY10P3S2T } \\
\text { engineered with } \Phi \text { C } 31 \text { recombinase and I-Scel } \\
\text { endonuclease expression systems } \\
\text { The prokaryotic backbone of PP harbors I-Scel } \\
\text { recognition sites (for MP and PP in vivo } \\
\text { degradation) and triplex DNA forming } \\
\text { sequences }\end{array}$ & $\begin{array}{l}\text { Mixture of elements commercially } \\
\text { available }\end{array}$ & $\begin{array}{l}\text { MC recovery of } 94-95 \% \\
\text { Removal of }>99 \% \text { PP and MP impurities }\end{array}$ \\
\hline $\begin{array}{l}\text { Anion exchange chromatography } \\
\text { Diamantino et al. (2016) }\end{array}$ & & Commercially available & $\begin{array}{l}\text { MC recovery of } 50 \% \\
1.15 \mathrm{ng} \text { gDNA/ } \mu \mathrm{g} \mathrm{MC} \text {; endotoxins } 10 \mathrm{EU} / \\
\mathrm{mg} \mathrm{MC} \text {, host cell proteins undetectable }\end{array}$ \\
\hline $\begin{array}{l}\text { Pseudo-affinity chromatography } \\
\text { Almeida et al. (2019) }\end{array}$ & $\begin{array}{l}\text { Commercially available E. coli ZYCY10P3S2T } \\
\text { engineered with } \Phi \text { C } 31 \text { recombinase and I-Scel } \\
\text { endonuclease expression systems. } \\
\text { PP harbors I-Scel recognition sites in the } \\
\text { prokaryotic backbone for MP and PP in vivo } \\
\text { degradation }\end{array}$ & $\begin{array}{l}\text { Commercially available monolith } \\
\text { subsequently modified with lysine } \\
\text { (1) or cadaverine (2) }\end{array}$ & $\begin{array}{l}\text { (1) No information available } \\
\text { (2) recovery of } 78.6 \% \mathrm{MC} \text { with a purity } \\
\text { of } 98.1 \% \\
1.6 \mathrm{ng} \mathrm{gDNA} / \mu \mathrm{g} \mathrm{MC} \text {; endotoxins } 10 \mathrm{EU} / \mathrm{mg} \\
\mathrm{MC} \text {, host cell proteins and RNA } \\
\text { undetectable }\end{array}$ \\
\hline $\begin{array}{l}\text { Size-exclusion chromatography } \\
\text { Almeida et al. (2020a) }\end{array}$ & & Commercially available & $\begin{array}{l}\text { Recovery of } 66.7 \% \text { MC with a purity } \\
\text { of } 98.4 \% \\
2 \text { ng gDNA } \mu \mathrm{g} \mathrm{MC} \text {; endotoxins } 11 \mathrm{EU} / \mathrm{mg} \\
\mathrm{MC} \text {, host cell proteins and RNA } \\
\text { undetectable }\end{array}$ \\
\hline
\end{tabular}

PP, parental plasmid; MP, miniplasmid; MC, minicircle.

Thus, the use of SEC can be a viable strategy for minicircle purification, at least within the size-range used in the work described above. However, of the chromatographic methods addressed in this work, SEC is by far the most time consuming, with optimized runs taking approximately $130 \mathrm{~min}$ to complete. Further, in the case of production schemes in which parental plasmid and miniplasmid are not degraded prior to SEC, the presence of these similarly-sized and topological equivalent impurities would hinder minicircle isolation. This is especially true for the case of miniplasmids, which would probably co-elute with minicircles.

\section{DISCUSSION}

Despite the demonstration that minicircle DNA have higher transfection efficiency and transgene expression than plasmid DNA in laboratory settings, minicircles have not yet been used in clinical trials. This fact is typically ascribed to the need for better manufacturing processes capable of producing minicircles required for the trials (Mairhofer and Grabherr 2008). Although progress has been made in this context, with the selection of better recombinase systems (Kay et al., 2010; Šimčíková et al., 2016) and fermentation processes (Gaspar et al., 2014), the major efforts are still registered in the downstream processing (e.g., Mayrhofer et al., 2008; Gaspar et al., 2013; Hou et al., 2015; Alves et al., 2016; Gaspar et al., 2017). A summary of the methods described in this review is given in Table 2. Additionally, the search for different ligands with high specificity to purify minicircles could be one of the leading paths to the development of more robust, reliable and cost-effective purification methods. In this context, a platform (Gaspar et al., 2013) was developed to screen ligand-minicircle interactions and identify potential ligands and binding/elution conditions.

It is noteworthy mentioning that some purification processes are still in a very early research stage and need to be further explored to validate their applicability and robustness at large-scale. This category includes the HIC and triple-helix affinity methods described in sections "Hydrophobic Interaction Chromatography" and "Triple-Helix Affinity Purification", respectively, for which a thorough analysis of the final products should be performed to confirm that the recovered minicircle complies with regulatory guidelines in terms of impurity content. Also, the triple-helix affinity method should be evaluated in terms of its cost- 
effectiveness, scalability and robustness at a larger scale. As for the immobilization of minicircles in bacterial ghosts described in "Immobilization in Bacterial Ghosts" section, several aspects should be addressed. Firstly, the method presented constitutes a proof of principle study. While the successful in vivo immobilization of minicircles in the bacterial ghost was shown, neither transgene expression nor the elicitation of an immune response were demonstrated. To the best of our knowledge, bacterial ghosts production and their loading with the plasmid vector were performed in a two-step protocol. However, promising results in immune responses in human monocyte derived dendritic cells (Kudela et al., 2005) and gene deliver to melanoma cells (Kudela et al., 2008) and murine macrophages have been reported (Paukner et al., 2005). One possible advantage of the use of minicircles for loading of bacterial ghosts is their higher transgene expression due to the absence of prokaryotic backbone thus avoiding transgene silencing. Regarding the presence of LPS in the final product, studies indicate that these raise low safety concerns (Mader et al., 1997; Paukner et al., 2005; Langemann et al., 2010). Also, no toxic effect is observed by the use of pDNA-loaded bacterial ghosts in in vitro studies (Kudela et al., 2005, 2008). This is however a critical aspect and the effects of LPS presence would be required to be thoroughly evaluated to validate safety and possible therapeutic use of minicircles immobilized in these carrier vehicles. Efficient production at large scale (bioreactors of up to $20 \mathrm{~L}$ ) has been reported, being also taken into account in vivo protein expression induction (Langemann et al., 2010). Efficient process scale-up for minicircle bacterial ghosts would however require optimization of several process parameters such as culture temperature and induction time for successful and sequential minicircle production and inducible cell lysis.

This review analyses several methods described in the literature that showed successful supercoiled minicircle isolation. In theory these could be optimized to improve recovery yields and purities and to allow application at a process scale. The search for better production systems has led to the development of parental plasmid recombination strategies relying in different recombinase expression systems. Along the years, attempts at minicircle purification have resulted in the development of protocols with increased robustness, yield and affordability. However, the successful translation of minicircles from the laboratory scale to clinical applications requires further efforts in bioprocess engineering and in the development of methods for product quality control (Almeida et al., 2020b).

Overall, the purification techniques that can be used for minicircle purification are highly dependent on the upstream process and priorpurification steps that are applied to facilitate its separation from impurities. Chromatographic techniques such as hydrophobic interaction or anion exchange chromatography have been well established for plasmid DNA purification by taking advantage of the different interactions between the chromatographic matrix and the molecule of interest and impurities (e.g., gDNA, RNA). However, in the case of minicircles a more complex feed stream is obtained after production and thus additional actions have to be taken. This is of special relevance as the minicircles, miniplasmids and parental plasmid share similar topology and physicochemical characteristics, which would lead to their co-elution during a chromatographic protocol typically used for plasmid DNA purification. We have thus grouped the techniques that can be applied for minicircle isolation by taking into account the feed stream obtained after production. In the in vitro restriction approaches presented, the chromatographic step is designed to isolate supercoiled minicircles from a feed containing open circular DNA species (miniplasmid, parental plasmid and minicircle) and other impurities (e.g., gDNA and RNA). Although this allows the use of commercially available chromatographic matrices, due to the use of an enzyme in vitro these methods have a lengthier process time and might be of challenging and costly scale up. Regarding in vivo restriction strategy, one of its main advantages is the reduction of the impurity content during in vivo production. However, important key impurities are still present that need to be separated from the minicircle of interest. In this case, the feed stream is more closely comparable to what is obtained during a typical pDNA purification, where the chromatographic step is mostly intended to isolate the supercoiled molecule from key impurities such as RNA, gDNA, endotoxins and proteins. Thus, although chromatographic techniques such as anion exchange or amino acid pseudo affinity would not be able to distinguish miniplasmids from minicircles, they can be used to purify minicircles produced by in vivo steps that greatly reduce miniplasmid content. This strategy results in the successful minicircle isolation with a purity that is in accordance with regulatory guidelines, as illustrated by the cases presented.

One advantage of promoting the reduction of impurities in vivo is that it directly allows the use of readily available commercial chromatographic matrices. Ideally, an optimal purification platform would be based on affinity purification, as is the case of the RBPS technology. However, this matrix is not commercially available, although this could be a future possibility given the announced partnership with BIA Separations. We would also like to add that in this case the main drawback of the method (i.e. the introduction of a sequence that is not relevant for the therapeutic use of the minicircle of interest) could be avoided if affinity tags sequences were located in the prokaryotic backbone. This would then call for a chromatographic separation in negative mode where parental plasmid and miniplasmid would bind to the matrix. However, additional chromatographic steps would probably be required to reduce the content of other impurities to levels accepted by regulatory agencies.

In terms of process time, and as expected, SEC separations require the longest runs $(\approx 130 \mathrm{~min})$, while anion exchange allows completion of minicircle purification in a $30 \mathrm{~min}$ run. The time needed in other chromatographic alternatives is comparable, varying between 40 and $50 \mathrm{~min}$. However, it is important to mention that HIC and MMC require the inclusion of additional steps prior to chromatography, which will result in lengthier overall processes. The triple-helix affinity purification approach shows-disregarding the recovery of minicircle by ethanol precipitation - a similar purification time to SEC, being needed $2 \mathrm{~h}$ of incubation at the scale used to remove the impurities from the supernatant.

Cost-effectiveness should be taken into account, and for this reason the use of commercially available separation platforms is probably preferable. Special attention should also be given to strategies that facilitate the final separation of parental plasmid and miniplasmid impurities from the final minicircle product. In 
this light, additional sequences are typically introduced into the parental plasmid. Such sequences should be preferably located in the prokaryotic region that gives origin to the miniplasmid in order to not alter the eukaryotic cassette of interest in the minicircle. Overall, the progress of minicircle toward successful clinical applications is dependent on the establishment of robust and reproducible production and purification strategies.

\section{AUTHOR CONTRIBUTIONS}

All authors conceived the manuscript. CA wrote the manuscript which was then critically read and edited by GM and DP.

\section{REFERENCES}

Abdulrahman, A., and Ghanem, A. (2018). Recent advances in chromatographic purification of plasmid DNA for gene therapy and DNA vaccines: a review. Anal. Chim. Acta. 1025, 41-57. doi:10.1016/j.aca.2018.04.001

Almeida, A. M., Eusébio, D., Queiroz, J. A., Sousa, F., and Sousa, A. (2020a). The use of size-exclusion chromatography in the isolation of supercoiled minicircle DNA from Escherichia coli lysate. J. Chromatogr. A. 1609, 460444. doi:10.1016/ j.chroma.2019.460444

Almeida, A. M., Queiroz, J. A., Sousa, F., and Sousa, A. (2020b). Minicircle DNA: the future for DNA-Based vectors?. Trends Biotechnol. 38 (10), 1047-1051. doi:10.1016/j.tibtech.2020.04.008

Almeida, A. M., Queiroz, J. A., Sousa, F., and Sousa, A. (2019). Minicircle DNA purification: Performance of chromatographic monoliths bearing lysine and cadaverine ligands. J. Chromatogr. B. 1118-1119, 7-16. doi:10.1016/j.jchromb. 2019.04.024

Alves, C. P. A., Šimčíková, M., Brito, L., Monteiro, G. A., and F Prazeres, D. M. (2018). Production and purification of supercoiled minicircles by a combination of in vitro endonuclease nicking and hydrophobic interaction chromatography. Hum. Gene Ther. Methods. 29 (4), 157-168. doi:10.1089/hgtb.2018.046

Alves, C. P. A., Šimčíková, M., Brito, L., Monteiro, G. A., and Prazeres, D. M. F. (2016). Development of a nicking endonuclease-assisted method for the purification of minicircles. J. Chromatogr. A. 1443, 136-144. doi:10.1016/j. chroma.2016.03.035

Bakker, N. A. M., de Boer, R., Marie, C., Scherman, D., Haanen, J. B. A. G., Beijnen, J. H., et al. (2019). Small-scale GMP production of plasmid DNA using a simplified and fully disposable production method. J. Biotechnol. X. 2, 100007. doi:10.1016/j.btecx.2019.100007

Balaeff, A., Mahadevan, L., and Schulten, K. (2004). Structural basis for cooperative DNA binding by CAP and lac repressor. Structure. 12 (1), 123-132. doi:10. 1016/j.str.2003.12.004

BIA Separations (2018). News. Available at: https://www.biaseparations.com/en/ news-events/news/127/bia-separations-partners-with-rbps-technology-toprovide-large-scale-minicircle-dna-vector-production (Accessed July, 2020).

Bigger, B. W., Tolmachov, O., Collombet, J. M., Fragkos, M., Palaszewski, I., and Coutelle, C. (2001). An araC-controlled bacterial cre expression system to produce DNA minicircle vectors for nuclear and mitochondrial gene therapy. J. Biol. Chem. 276 (25), 23018-23027. doi:10.1074/jbc.M010873200

Bo, H., Wang, J., Chen, Q., Shen, H., Wu, F., Shao, H., et al. (2013). Using a single hydrophobic-interaction chromatography to purify pharmaceutical-grade supercoiled plasmid DNA from other isoforms. Pharm. Biol. 51 (1), 42-48. doi:10.3109/13880209.2012.703678

Černigoj, U., Vidic, U., Barut, M., Podgornik, A., Peterka, M., and Štrancar, A. (2013). A multimodal histamine ligand for chromatographic purification of plasmid DNA. J. Chromatogr. A. 1281, 87-93. doi:10.1016/j.chroma.2013. 01.058

Chen, Z-Y., He, C-Y., Ehrhardt, A., and A Kay, M. (2003). Minicircle DNA vectors devoid of bacterial DNA result in persistent and high-level transgene expression in vivo. Mol. Ther. 8 (3), 495-500. doi:10.1016/s1525-0016(03)00168-0

\section{FUNDING}

Cláudia Alves studies are funded by FCT-Portuguese Foundation for Science and Technology (Grant PD/BD/116842/2016, BIOTECnico Ph.D. program).

\section{ACKNOWLEDGMENTS}

Funding received by iBB-Institute for Bioengineering and Biosciences from FCT-Portuguese Foundation for Science and Technology (Grant UIDB/04565/2020) and from Programa Operacional Regional de Lisboa 2020 (Project No. 007317) is acknowledged.

Costioli, M. D., Fisch, I., Garret-Flaudy, F., Hilbrig, F., and Freitag, R. (2001). DNA purification by triple-helix affinity precipitation. Biotechnol. Bioeng. 81 (5), 535-545. doi:10.1002/bit.10497

Darby, R. A. J., and Hine, A. V. (2005). LacI-mediated sequence-specific affinity purification of plasmid DNA for therapeutic applications. Faseb. J. 19, 1-20. doi:10.1096/fj.04-2812fje

Darquet, A. M., Cameron, B., Wils, P., Scherman, D., and Crouzet, J. (1997). A new DNA vehicle for nonviral gene delivery: supercoiled minicircle. Gene Ther. 4 (12), 1341-1349. doi:10.1038/sj.gt.3300540

Diamantino, T., Pereira, P., Queiroz, J. A., Sousa, A., and Sousa, F. (2016). Minicircle DNA purification using a CIM DEAE-1 monolithic support. J. Separ. Sci. 39, 3544-3549. doi:10.1002/jssc.201600375

Dietz, W. M., Skinner, N. E., Hamilton, S. E., Jund, M. D., Heitfeld, S. M., Litterman, A. J., et al. (2013). Minicircle DNA is superior to plasmid DNA in eliciting antigen-specific CD8+ T-cell responses. Mol. Ther. 21 (8), 1526-1535. doi:10.1038/mt.2013.85

Diogo, M. M., Queiroz, J. A., and F Prazeres, D. M. (2005). Chromatography of plasmid DNA. J. Chromatogr. A. 1069 (1), 3-22. doi:10.1016/j.chroma.2004. 09.050

Diogo, M. M., Queiroz, J. A., Monteiro, G. A., Martins, S. A., N Ferreira, G., and F Prazeres, D. M.. (2000). Purification of a cystic fibrosis plasmid vector for gene therapy using hydrophobic interaction chromatography. Biotechnol. Bioeng. 68, 576-583. doi:10.1002/(SICI)1097-0290(20000605)68:5<576::AID-BIT13>3.0

EMA - Committee for Advanced Therapies (2018). Guideline on the quality, nonclinical and clinical aspects of gene therapy medicinal products. Rome: European Medicines Agency.

Eon-Duval, A., and Burke, G. (2004). Purification of pharmaceutical-grade plasmid DNA by anion-exchange chromatography in an RNase-free process. J. Chromatogr. B. 804 (2), 327-335. doi:10.1016/j.jchromb.2004.01.033

FDA - Center for Biologics Evaluation and Research (2007). Guidance for industry: considerations for plasmid DNA vaccines for infectious disease indications. New York, NY: U.S. Department of Health and Human Services, Food and Drug Administration.

Ferreira, G. N. M., Monteiro, G. A., Prazeres, D. M. F., and S Cabral, J. M. (2000). Downstream processing of plasmid DNA for gene theraphy and DNA vaccine applications. Trends Biotechnol. 18 (9), 380-388. doi:10.1016/s0167-7799(00) 01475-x

Forde, G. M., Ghose, S., Slater, N. K. H., Hine, A. V., Darby, R. A. J., and Hitchcock, A. G. (2006). LacO-LacI interaction in affinity adsorption of plasmid DNA. Biotechnol. Bioeng. 95 (1), 67-75. doi:10.1002/bit.20955

Freitas, S. S., Santos, J. A. L., and Prazeres, D. M. F. (2009). Plasmid purification by hydrophobic interaction chromatography using sodium citrate in the mobile phase. Separ. Purif. Technol. 65 (1), 95-104. doi:10.1016/j.seppur.2008.04.001

Gaspar, V. M., Cruz, C., Queiroz, J. A., Pichon, C., Correia, I. J., and Sousa, F. (2017). Highly selective capture of minicircle DNA biopharmaceuticals by a novel zinc-histidine peptide conjugate. Separ. Purif. Technol. 174, 417-424. doi:10.1016/j.seppur.2016.10.054

Gaspar, V. M., Cruz, C., Queiroz, J. A., Pichon, C., Correia, I. J., and Sousa, F. (2013). Sensitive detection of peptide-minicircle DNA interactions by surface plasmon resonance. Anal. Chem. 85 (4), 2304-2311. doi:10.1021/ac303288x 
Gaspar, V. M., Maia, C. J., Queiroz, J. A., Pichon, C., Correia, I. J., and Sousa, F. (2014). Improved minicircle DNA biosynthesis for gene therapy applications. Hum. Gene Ther. Methods. 25 (2), 93-105. doi:10.1089/hgtb.2013.020

Gaspar, V. M., Melo-Diogo, D., Costa, E., Moreira, A., Queiroz, J., Pichon, C., et al. (2015). Minicircle DNA vectors for gene therapy: advances and applications. Expet Opin. Biol. Ther. 15 (3), 353-379. doi:10.1517/14712598.2015.996544

Ghanem, A., Healey, R., and Adly, F. G. (2013). Current trends in separation of plasmid DNA vaccines: a review. Anal. Chim. Acta. 760, 1-15. doi:10.1016/j.aca. 2012.11.006

Hajam, I. A., Dar, P. A., Won, G., and Lee, J. H. (2017). Bacterial ghosts as adjuvants: mechanisms and potential. Vet. Res. 48 (1), 37. doi:10.1186/s13567017-0442-5

Halan, V., Maity, S., Bhambure, R., and Rathore, A. S. (2019). Multimodal chromatography for purification of biotherapeutics-a review. Curr. Protein Pept. Sci. 20 (1), 4-13. doi:10.2174/1389203718666171020103559

Hardee, C. L., Arévalo-Soliz, L. M., Hornstein, B. D., and Zechiedrich, L. (2017). Advances in non-viral DNA vectors for gene therapy. Genes. 8 (2), E65. doi:10. 3390/genes 8020065

Hasche, A., and Voß, C. (2005). Immobilisation of a repressor protein for binding of plasmid DNA. J. Chromatogr. A. 1080 (1), 76-82. doi:10.1016/j.chroma.2005. 05.025

Heiter, D. F., Lunnen, K. D., and Wilson, G. G. (2005). Site-specific DNA-nicking mutants of the heterodimeric restriction endonuclease R.BbvCI. J. Mol. Biol. 348 (3), 631-640. doi:10.1016/j.jmb.2005.02.034

Hoffman, M. M., Khrapov, M. A., Cox, J. C., Yao, J., Tong, L., and Ellington, A. D. (2004). AANT: the amino acid-nucleotide interaction database. Nucleic Acids Res. 32 (Database issue), D174-D181. doi:10.1093/nar/gkh128

Holstein, M., Mesa-Nuñez, C., Miskey, C., Almarza, E., Pletti, V., Schmeer, M., et al. (2018). Efficient non-viral gene delivery into human hematopoietic stem cells by minicircle sleeping beauty transposon vectors. Mol. Ther. 26 (4), 1137-1153. doi:10.1016/j.ymthe.2018.01.012

Hou, X. H., Guo, X. Y., Chen, Y., He, C-Y., and Chen, Z-Y. (2015). Increasing the minicircle DNA purity using an enhanced triplex DNA technology to eliminate DNA contaminants. Mol. Ther. Methods Clin. Dev. 1, 14062. doi:10.1038/mtm. 2014.62

Jechlinger, W., Tabrizi, C. A., Lubitz, W., and Mayrhofer, P. (2004). Minicircle DNA immobilized in bacterial ghosts: in vivo production of safe non-viral DNA delivery vehicles. J. Mol. Microbiol. Biotechnol. 8 (4), 222-231. doi:10.1159/ 000086703

Jia, F., Wilson, K. D., Sun, N., Gupta, D. M., Huang, M., Li, Z., et al. (2010). A nonviral minicircle vector for deriving human iPS cells. Nat. Methods. 7 (3), 197-199. doi:10.1038/nmeth.1426

Jobe, A., and Bourgeois, S. (1972). Lac repressor-operator interaction: VI. The natural inducer of the lac operon. J. Mol. Biol. 69 (3), 397-408. doi:10.1016/ 0022-2836(72)90253-7

Kallberg, K., Johansson, H-O., and Bulow, L. (2012). Multimodal chromatography: an efficient tool in downstream processing of proteins. Biotechnol. J. 7 (12), 1485-1495. doi:10.1002/biot.201200074

Kay, M. A., He, C-Y., and Chen, Z-Y. (2010). A robust system for production of minicircle DNA vectors. Nat. Biotechnol. 28 (12), 1287-1289. doi:10.1038/nbt.1708

Kay, M. A. (2011). State-of-the-art gene-based therapies: the road ahead. Nat. Rev. Genet. 12 (5), 316-328. doi:10.1038/nrg2971

Kudela, P., Paukner, S., Mayr, U. B., Cholujova, D., Kohl, G., Schwarczova, Z., et al. (2008). Effective gene transfer to melanoma cells using bacterial ghosts. Canc. Lett. 262 (1), 54-63. doi:10.1016/j.canlet.2007.11.031

Kudela, P., Paukner, S., Mayr, U. B., Cholujova, D., Schwarczova, Z., Sedlak, J., et al. (2005). Bacterial ghosts as novel efficient targeting vehicles for DNA delivery to the human monocyte-derived dendritic cells. J. Immunother. 28 (2), 136-143. doi:10.1097/01.cji.0000154246.89630.6f

Langemann, T., Koller, V. J., Muhammad, A., Kudela, P., Mayr, U. B., and Lubitz, W. (2010). The Bacterial Ghost platform system: production and applications. Bioeng. Bugs. 1 (5), 326-336. doi:10.4161/bbug.1.5.12540

Latulippe, D. R., and Zydney, A. L. (2009). Size exclusion chromatography of plasmid DNA isoforms. J. Chromatogr. A. 1216 (35), 6295-6302. doi:10.1016/j. chroma.2009.07.009

Li, H., Bo, H., Wang, J., Shao, H., and Huang, S. (2011). Separation of supercoiled from open circular forms of plasmid DNA, and biological activity detection. Cytotechnology. 63 (1), 7-12. doi:10.1007/s10616-010-9322-9
Li, L-Z., Liu, Y., Sun, M-S., and Shao, Y-M. (2007). Effect of salt on purification of plasmid DNA using size-exclusion chromatography. J. Chromatogr. A. 1139 (2), 228-235. doi:10.1016/j.chroma.2006.11.027

Luscombe, N. M., Laskowski, R. A., and Thornton, J. M. (2001). Amino acid-base interactions: a three-dimensional analysis of protein-DNA interations at an atomic level. Nucleic Acids Res. 29 (13), 2860-2874. doi:10.1093/nar/29.13.2860

Mader, H. J., Szostak, M. P., Hensel, A., Lubitz, W., and Haslberger, A. G. (1997). Endotoxicity does not limit the use of bacterial ghosts as candidate vaccines. Vaccine. 15 (2), 195-202. doi:10.1016/s0264-410x(96)00141-7

Mairhofer, J., and Grabherr, R. (2008). Rational vector design for efficient non-viral gene delivery: challenges facing the use of plasmid DNA. Mol. Biotechnol. 39 (2), 97-104. doi:10.1007/s12033-008-9046-7

Matos, T., Queiroz, J. A., and Bülow, L. (2013). Plasmid DNA purification using a multimodal chromatography resin. J. Mol. Recogn. 27 (4), 184-189. doi:10. $1002 /$ jmr.2349

Mayrhofer, P., Blaesen, M., Schleef, M., and Jechlinger, W. (2008). Minicircle-DNA production by site-specific recombination and protein-DNA interaction chromatography. J. Gene Med. 10 (11), 1253-1269. doi:10.1002/jgm.1243

Mayrhofer, P., and Iro, M. (2012). "Minicircle-DNA," in Gene vaccines. Editors J. Thalhamer, R. Weiss, and S. Scheiblhofer (Springer-Verlag Wien), 297-310.

Monjezi, R., Miskey, C., Gogishvili, T., Schleef, M., Schmeer, M., Einsele, H., et al. (2017). Enhanced CAR T-cell engineering using non-viral Sleeping Beauty transposition from minicircle vectors. Leukemia. 31 (1), 186-194. doi:10.1038/ leu.2016.180

Mwau, M., Cebere, I., Sutton, J., Chikoti, P., Winstone, N., Wee, E. G-T., et al. (2004). A human immunodeficiency virus 1 (HIV-a) clade A vaccine in clinical trials: stimulation of HIV-specific T-cell responses by DNA and recombinant modified vaccine virus Ankara (MVA) vaccines in humans. J. Gen. Virol. 85 (Pt4), 911-919. doi:10.1099/vir.0.19701-0

Nehlsen, K., Broll, S., and Bode, J. (2006). Replicating minicircles: generation of nonviral episomes for the efficient modification of dividing cells. Gene Ther. Mol. Biol. 10, 233-244.

Paukner, S., Kudela, P., Kohl, G., Schlapp, T., Friedrichs, S., and Lubitz, W. (2005). DNA-loaded bacterial ghosts efficiently mediate reporter gene transfer and expression in macrophages. Mol. Ther. 11 (2), 215-223. doi:10.1016/j.ymthe. 2004.09.024

Paukner, S., Stiedl, T., Kudela, P., Bizik, J., Laham, F. A., and Lubitz, W. (2006). Bacterial ghosts as a novel advanced targeting system for drug and DNA delivery. Expet Opin. Drug Deliv. 3 (1), 11-22. doi:10.1517/17425247.3.1.11

Prather, K. J., Sagar, S., Murphy, J., and Chartrain, M. (2003). Industrial scale production of plasmid DNA for vaccine and gene therapy: plasmid design, production, and purification. Enzym. Microb. Technol. 33 (7), 865-883. doi:10. 1016/S0141-0229(03)00205-9

Prazeres, D. M. F., and Monteiro, G. A. (2014). Plasmid biopharmaceuticals. Microbiol. Spectr. 2 (6) . doi:10.1128/microbiolspec.PLAS-0022-2014

Prazeres, D. M. F. (2011). Plasmid biopharmaceuticals: basics, applications, and manufacturing. Part III manufacturing. Hoboken: John Wiley \& Sons, Inc., 327-562.

Prazeres, D. M. F., Schluep, T., and Cooney, C. (1998). Preparative purification of supercoiled plasmid DNA using anion-exchange chromatography. J. Chromatogr. A. 806 (1), 31-45. doi:10.1016/s0021-9673(97)01254-5

Quaak, S. G. L., van der Berg, J. H., Toebes, M., Schumacher, T. N. M., Haanen, J. B. A. G., Beijnen, J. H., et al. (2008). GMP production of pDERMATT for vaccination against melanoma in a phase I clinical trial. Eur. J. Pharm. Biopharm. 70 (2), 429-438. doi:10.1016/j.ejpb.2008.05.002

Rader, R. A. (2008). (Re)defining biopharmaceutical. Nat. Biotechnol. 26 (7), 743-751. doi:10.1038/nbt0708-743

Schleef, M., Blaesen, M., Schmeer, M., Baier, R., Marie, C., Dickson, G., et al. (2010). Production of non viral DNA vectors. Curr. Gene Ther. 10 (6), 487-507. doi:10. 2174/156652310793797711

Schluep, T., and Cooney, C. L. (1998). Purification of plasmids by triplex affinity interaction. Nucleic Acids Res. 26 (19), 4524-4528. doi:10.1093/nar/26.19.4524

Shankar, R., Schmeer, M., and Schleef, M. (2017). Minicircles: next-generation gene vectors. Cell Gene Therapy Insights. 3 (2), 285-300. doi:10.18609/cgti.2017.020

Silva-Santos, A. R., Alves, C. P. A., Monteiro, G., Azevedo, A. M., and Prazeres, D. M. F. (2019). Multimodal chromatography of supercoiled minicircles: a closer look into DNA-ligand interactions. Separ. Purif. Technol. 212, 161-170. doi:10. 1016/j.seppur.2018.11.015 
Silva-Santos, A. R., Alves, C. P. A., Prazeres, D. M. F., and Azevedo, A. M. (2017). A process for supercoiled plasmid DNA purification based on multimodal chromatography. Separ. Purif. Technol. 182, 94-100. doi:10.1016/j.seppur. 2017.03.042

Silva-Santos, A. R., Alves, C. P. A., Prazeres, D. M. F., and Azevedo, A. M. (2016). Separation of plasmid DNA topoisomers by multimodal chromatography. Anal. Biochem. 503, 68-70. doi:10.1016/j.ab.2016.03.012

Šimčíková, M., Alves, C. P. A., Brito, L., J Prather, K. L., Prazeres, D. M. F., and Monteiro, G. A. (2016). Improvement of DNA minicircle production by optimization of the secondary structure of the $5^{\prime}$-UTR of ParA resolvase. Appl. Microbiol. Biotechnol. 100 (15), 6725-6737. doi:10.1007/s00253-016$7565-\mathrm{x}$

Šimčíková, M., J Prather, K. L., Prazeres, D. M. F., and Monteiro, G. A. (2014). On the dual effect of glucose during production of $\mathrm{pBAD} / \mathrm{AraC}$-based minicircles. Vaccine. 32 (24), 2843-2846. doi:10.1016/j.vaccine.2014.02.035

Sousa, A., Sousa, F., and Queiroz, J. A. (2009). Biorecognition of supercoiled plasmid DNA isoform in lysine-affinity chromatography. J. Chromatogr. B. 877 (27), 3257-3260. doi:10.1016/j.jchromb.2009.08.021

Sousa, F., Cruz, C., and Queiroz, J. A. (2010). Amino acids-nucleotides biomolecular recognition: from biological occurence to affinity chromatography. J. Mol. Recogn. 23 (6), 505-518. doi:10.1002/jmr.1053

Sousa, F., Freitas, S., Azzoni, A. R., F Prazeres, D. M., and Queiroz, J. (2006). Selective purification of supercoiled plasmid DNA from clarified cell lysates with a single histidine-agarose chromatography step. Biotechnol. Appl. Biochem. 45 (Pt 3), 131-140. doi:10.1042/BA20060082

Sousa, F., Matos, T., Prazeres, D. M. F., and Queiroz, J. A. (2008b). Specific recognition of supercoiled DNA in arginine affinity chromatography. Anal. Biochem. 374 (2), 432-434. doi:10.1016/j.ab.2007.11.005

Sousa, F., Prazeres, D. M. F., and Queiroz, J. A. (2008a). Affinity chromatography approaches to overcome the challenges of purifying plasmid DNA. Trends Biotechnol. 26 (9), 518-525. doi:10.1016/j.tibtech.2008.05.005

Tolmachov, O. (2010). Tightly-wound miniknot vectors for gene therapy: a potential improvement over supercoiled minicircle DNA. Med. Hypotheses. 74 (4), 702-704. doi:10.1016/j.mehy.2009.10.035

Uludag, H., Ubeda, A., and Ansari, A. (2019). At the intersection of biomaterials and gene therapy: progress in non-viral delivery of nucleic acids. Front. Bioeng. Biotechnol. 7, 131. doi:10.3389/fbioe.2019.00131

Urthaler, J., Buchinger, W., and Necina, R. (2005). Industrial scale cGMP purification of pharmaceutical grade plasmid-DNA. Chem. Eng. Technol. 28 (11), 1408-1420. doi:10.1002/ceat.200500126
Urthaler, J., Schuchnigg, H., Garidel, P., and Huber, H., (2012). "Industrial manufacturing of plasmid-DNA products for gene vaccination and therapy,". Editors J. Thalhamer, R. Weiss, and S. Scheiblhofer (Berlin: Springer-Verlag Wien), 311-330.

Walsh, G. (2003). Biopharmaceuticals benchmarks-2003. Nat. Biotechnol. 21 (8), 865-870. doi:10.1038/nbt0803-865

Walsh, G. (2018). Biopharmaceuticals benchmarks 2018. Nat. Biotechnol. 36 (12), 1136-1145. doi:10.1038/nbt.4305

Wang, H., Ye, X., Ju, Y., Cai, Z., Wang, X., Du, P., et al. (2020). Minicircle DNAmediated CAR T cells targeting CD44 supressed hepatocellular carcinoma both in vitro and in vivo. OncoTargets Ther. 13, 3703-3716. doi:10.2147/OTT. S247836

Wang, Q., Jiang, W., Chen, Y., Liu, P., Sheng, C., Chen, S., et al. (2014). In vivo electroporation of minicircle DNA as a novel method of vaccine delivery to enhance HIV-1-specific immune responses. J. Virol. 88 (4), 1924-1934. doi:10. 1128/JVI.02757-13

Wiley (2019). Gene therapy clinical trials worldwide. Available at: http://www. abedia.com/wiley/ (Accessed July, 2020).

Wils, P., Escriou, V., Warnery, A., Lacroix, F., Lagneaux, D., Ollivier, M., et al. (1997). Efficient purification of plasmid DNA for gene transfer using triplehelix affinity chromatography. Gene Ther. 4 (4), 323-330. doi:10.1038/sj.gt. 3300388

Zang, K., and Liu, X. (2016). Mixed-mode chromatography in pharmaceutical and biopharmaceutical applications. J. Pharm. Biomed. 128, 73-88. doi:10.1016/j. jpba.2016.05.007

Zhao, G., Dong, X-Y., and Sun, Y. (2009). Ligands for mixed-mode protein chromatography: principles, characteristics and design. J. Biotechnol. 144 (1), 3-11. doi:10.1016/j.jbiotec.2009.04.009

Conflict of Interest: The authors declare that the research was conducted in the absence of any commercial or financial relationships that could be construed as a potential conflict of interest.

Copyright (๑) 2021 Alves, Prazeres and Monteiro. This is an open-access article distributed under the terms of the Creative Commons Attribution License (CC BY). The use, distribution or reproduction in other forums is permitted, provided the original author(s) and the copyright owner(s) are credited and that the original publication in this journal is cited, in accordance with accepted academic practice. No use, distribution or reproduction is permitted which does not comply with these terms. 